\title{
Associated factors vs risk factors in cross-sectional studies
}

David Antay-Bedregal'

Evelyn Camargo-Revello' German F Alvarado²

'Escuela de Terapia Física, Universidad Peruana de Ciencias Aplicadas, Lima, Perú; '2Escuela de Medicina, Universidad Peruana de Ciencias Aplicadas, Lima, Perú
Correspondence: David Antay-Bedregal Escuela de Terapia Física, Universidad Peruana de Ciencias Aplicadas,

Av Alameda San Marcos Block 2

Chorrillos, Lima, Perú

$\mathrm{Tel}+5$ I I 313333

Email drab23.07@gmail.com
This article was published in the following Dove Press journal:

Patient Preference and Adherence

13 November 2015

Number of times this article has been viewed

\section{Dear editor}

We have read with great interest the study of Karukunchit et al ${ }^{1}$ published in Patient Preference and Adherence. This study is important because it investigates a health problem that has not been well studied. However, we have some comments:

a) It should be noted that cross-sectional studies are the best choice when the aim of the research is to estimate the prevalence of a characteristic in a specific population, they may also be useful if we wish to evaluate factors associated with a disease or condition. ${ }^{2}$ On the other hand, when we wish to evaluate risk factors, we need to estimate the incidence; this measure of occurrence can be computed in longitudinal studies (involving follow-up); clear examples of this are cohort studies. That is why cross-sectional studies can only estimate the prevalence and associated factors of a condition or disease, unless we can assure temporality. ${ }^{3}$

b) Another comment that we would like to make is about the use of odds ratio vs prevalence ratio. When working with a frequent outcome in the context of a crosssectional study, the use of the odds ratio overestimates the association. ${ }^{4,5}$ In the study of Karukunchit et al, ${ }^{1}$ the outcome is frequent, therefore, the use of prevalence ratio would have been a better measure of association.

\section{Disclosure}

The authors report no conflicts of interest in this communication.

\section{References}

1. Karukunchit U, Puntumetakul R, Swangnetr M, Boucaut R. Prevalence and risk factor analysis of lower extremity abnormal alignment characteristics among rice farmers. Patient Prefer Adherence. 2015; 9:785-795.

2. Barroga E. Research study designs: an appraisal for peer reviewers and science editors. European Science Editing. 2013;39(2):44-45.

3. Gordis L. Epidemiology. 5th ed. Philadelphia: Saunders Elsevier; 2014.

4. Barros AJ, Hirakata VN. Alternatives for logistic regression in cross-sectional studies: an empirical comparison of models that directly estimate the prevalence ratio. BMC Med Res Methodol. 2003;3:21.

5. Axelson O, Fredriksson M, Ekberg K. Use of the prevalence ratio v the prevalence odds ratio as a measure of risk in cross sectional studies. Occup Environ Med. 1994;51(8):574. 


\section{Authors' reply}

\section{Rungthip Puntumetakul ${ }^{1,2}$ \\ Usa Karukunchit ${ }^{1,3}$}

'Research Center in Back, Neck, Other Joint Pain and Human Performance (BNOJPH), Khon Kaen University, Khon Kaen, Thailand; ${ }^{2}$ School of Physical Therapy, Faculty of Associated Medical Sciences, Khon Kaen University, Khon Kaen, Thailand; ${ }^{3}$ Faculty of Associated Medical Sciences, Khon Kaen University, Khon Kaen, Thailand

Correspondence: Rungthip Puntumetakul

Research Center in Back, Neck, Other Joint Pain and Human

Performance (BNOJPH), I 23 Khon Kaen University, Mitraphab Street,

Muang District, Khon Kaen 40002, Thailand

Tel +66834196186

Fax +6643202399

Email rungthiprt@gmail.com

\section{Dear editor}

Thank you very much for taking the time to read our paper and for your helpful critique on our method and measures.

We note the difference between prevalence and risk factors and agree that a cohort study would have been a more useful approach. However, the disadvantages of using a cohort study design were threefold: (1) participants must be followed over a prolonged period of time for observations; (2) the possible loss of study participants to follow up; and (3) high costs. Moreover, in a retrospective cohort study the investigators must collect historical data on risk factors. ${ }^{1,2}$ In our study we did not collect historical data on risk factors such as body mass index and occupational characteristics.

Thank you for also pointing out the fact that a prevalence ratio would have been a preferred measure and that an odds ratio may have over-estimated the prevalence. Reading the articles you referred to in your comments has furthered our understanding about this preferred measure. However, most of the recent studies we reviewed showed that the odds ratio (OR) remains the most popular measure of the exposure disease relationship in epidemiology. ${ }^{3-6}$ The OR has an important role in describing the results of cross-sectional studies, mainly due to mathematical convenience and the easy availability of advanced statistical or logistic regression analysis. Therefore, we reported the OR to evaluate risk factor associations. ${ }^{2}$

\section{Disclosure}

The authors report no conflicts of interest in this communication.

\section{References}

1. Jekel J, Katz D, Elmore J, Wild D. Epidemiology, Biostatistics, and Preventive Medicine. 3rd ed. Philadelphia: Sauders Elsevier; 2007.

2. Hulley SB, Cummings SR, Browner WS, Grady DG, Newman TB. Designing clinical research. 3rd ed. Philadelphia: Lippincott Williams and Wilkins; 2007.

3. Yu S, Lu M, Gu G, Zhou W, He L, Wang S. Musculoskeletal symptoms and associated risk factors in a large sample of Chinese workers in Henan province of China. Am J Ind Med. 2012;55(3):281-293.

4. Bezu H, Seifu D, Yimer G, Mebrhatu T. Prevalence and risk factors of adverse drug reactions associated multidrug resistant tuberculosis treatments in selected treatment centers in Addis Ababa Ethiopia. JTR. 2014;2(3):144-154.

5. Deleré Y, Remschmidt C, Leuschner J, et al. Human Papillomavirus prevalence and probable first effects of vaccination in 20 to 25 year-old women in Germany: a population-based crosssectional study via homebased self-sampling. BMC Infect Dis. 2014;14:87.

6. Meksawi S, Tangtrakulwanich B, Chongsuvivatwong V. Musculoskeletal problems and ergonomic risk assessment in rubber tappers: a communitybased study in southern Thailand. Int J Ind Ergonom. 2012;42(1): $129-135$.

Dove Medical Press encourages responsible, free and frank academic debate. The content of the Patient Preference and Adherence 'letters to the editor' section does not necessarily represent the views of Dove Medical Press, its officers, agents, employees, related entities or the Patient Preference and Adherence editors. While all reasonable steps have been taken to confirm the content of each letter, Dove Medical Press accepts no liability in respect of the content of any letter, nor is it responsible for the content and accuracy of any letter to the editor.

\section{Publish your work in this journal}

Patient Preference and Adherence is an international, peer-reviewed, open access journal that focuses on the growing importance of patient preference and adherence throughout the therapeutic continuum. Patient satisfaction, acceptability, quality of life, compliance, persistence and their role in developing new therapeutic modalities and compounds to optimize clinical outcomes for existing disease states are major areas of interest for the journal. This journal has been accepted for indexing on PubMed Central. The manuscript management system is completely online and includes a very quick and fair peer-review system, which is all easy to use. Visit http://www dovepress.com/testimonials.php to read real quotes from published authors. 